\title{
Another modest proposal? Science and seriality in Mo Yan's novel Wa (frogs)
}

\author{
Andrea Riemenschnitter
}

Received: 10 October 2013/Revised: 10 October 2013/Accepted: 10 October 2013/

Published online: 2 April 2014

(C) Academy for International Communication of Chinese Culture and Springer-Verlag Berlin Heidelberg 2014

\begin{abstract}
European Enlightenment thought was the privileged model upon which intellectuals built a Chinese modernity since the decline of the Qing dynasty in the late nineteenth century. Aesthetically, a turn towards literary realism was successfully implemented. These Western legacies dominated the literary field until they lost their persuasive power in the 1990s. Beyond cultural production, the entanglements of a nation in transition with Eurocentric ideological paradigms influenced statecraft and nationalistic thought to our days. In his novel Frogs Mo Yan revisits the heritage of May Fourth modernism to expose its transmogrification into the dehumanizing reality effects accompanying birth control from Mao to the Deng regime and thereafter. Employing images that suggest recent, science-based governance to have triggered local regimes of cosmic un-creation, the novel focuses on a global modernization that is perceived as socially as well as environmentally destructive.
\end{abstract}

Keywords Modernity $\cdot$ One-child policy $\cdot$ Science $\cdot$ Enlightenment . Realism · Myth · Industrial serialization · Disposable bodies · The abject

\section{Introduction}

In view of the changing demands of the global capitalist market and after having been the battered epicenter of revolutions for the larger part of the twentieth century, China successfully changed its policies since the 1980s. At the beginning of the new millennium it is actively repositioning itself as one of the leading world powers. However, the negative effects of a heated economic development are now

\footnotetext{
A. Riemenschnitter $(\bowtie)$

Institute of Asian and Oriental Studies, University of Zurich, Zurich, Switzerland

e-mail: andrea.riemenschnitter@aoi.uzh.ch
} 
increasingly overshadowing its progress. These problems are not new, but increasingly serious in a country that has a long history of unsustainable population growth in the face of limited natural resources. In the Western hemisphere an awareness of the possible side effects of uncontrolled economic growth was articulated since the early 1970s. Pleadings for collective investment in a sustainable planetary future first emanated from the Club of Rome ${ }^{1}$; in their predilection for statistical data the policy guidelines published by members of the Club of Rome were firmly rooted in enlightenment values. A science-based campaign for a tight control over global population and economic growth was brought to life by this global association of economic leaders and eminent scientists. However, their personal economic and career interests somehow stood in the light of the humanist orientation of these stakeholders. In fact, their planetary critique of unlimited growth credos has not changed the world (or history, as announced on the homepage) after more than 40 years of their engagement. ${ }^{2}$ Their programme of governance based on statistical data for the prognosis of macroeconomic trends was not new, either: it reaches back to the formation of demography as an academic discipline in the early eighteenth century (Neurath 1994). In the wake of emerging Asian powers currently in the process of defining a polycentric, inter-imperial global order for the twenty-first century, a new, globally accountable moral regime is required. Neither the heightened awareness about problems related to economic over-development through the sometimes spectacular campaigns led by global NGOs such as Greenpeace, or even the text- and data-based persuasions of the Club of Rome, nor the European enlightenment-based, rationalist ideology that has created our predominate global capitalist model seem to be capable of spurring overdue reforms.

When China after its successful yet unthrifty resistance against western imperialism opened its doors to global markets the ruling elite turned away from Mao's doctrines of rigorous social modelling-implying revolutionary terror-for the reconstruction of China as a modern nation. Science was believed to be the new key to a harmonious development at all levels of governance. Birth control continued to be ranked prominently on the state agenda, but the policy changed. Executives began to monitor the data, methods and arguments for population control that were disseminated by the Club of Rome. A scientist was sent to Helsinki to observe the Seventh Triennial World Congress of the International Federation of Automatic Control in 1978. Upon his report, a new regime of birth control was implemented that was exclusively based on statistical numbers and quota. The social effects of this science-based growth control were particularly drastic in rural areas, but could not be publicly discussed. In this way, science paradoxically turned into a pseudo-religious belief system: progress was the unquestioned and underdefined telos of a wholesale industrial serialization of social

\footnotetext{
1 The Club of Rome was founded in 1968, bringing together personalities from politics, business and science who were 'interested in contributing in a systemic interdisciplinary and holistic manner to a better world'. For more detailed information see www.clubofrome.org (Accessed 18 Nov 2012).

2 As any other critical stand-off from the late capitalist credo, this critique of the myth of infinite economic growth was quickly translated into yet another consumption pattern: the myth of the ethical consumer was born. See Devinney et al. (2010).
} 
life. After more than 30 years of rapid economic growth and strict birth control, China has become a threshold country that is not only benefiting from its capitalist turn, but at the same time suffers from the negative impact of its enduringly unsustainable politics of modernization on a rapidly disintegrating society. At the same time, it has entered a realm of global economic struggles, competing with the other economic giants for markets, resources and legitimacy.

Among the most worrying social effects of the emergent multipolar capitalist system is the growing gap between the rich and poor population segments within and beyond national borderlines. Together with reports on flood and drought disasters in the wake of global warming, massive air and water pollution and impending military conflict over contested natural resources, even the national media no longer gloss over rising crime rates, irresponsible behavior of employers, or even cadre corruption in the context of land grabbing. At the same time, the commodified human body has moved to center stage - in China's political economy as elsewhere. With human trafficking and the exhaustion of bodies in cheap labor on one end, and the production of precious bodies in a booming beauty-cum-health industry as well as a trade in body parts and substitutes in biogenetic enterprises on the other end of the scale, China participates in a global body traffic, which concerned scholars animadvert as inhuman, unethical economic practice (Braidotti 2006; Cheah 2006; Chow 2007; Haraway 2008; Miller 2006; Shelley 2010; Wilkinson 2003).

Pheng Cheah, a scholar of South East Asian post-colonial struggles, analyzed the rhetorical mechanisms that modernizing states employ to simultaneously produce, support and conceal such undesired yet widely tolerated social realities. His study on the inhuman conditions of globalizing economies explains how seemingly incongruous cases - like the nationalistic appeal for solidarity with the battered state of China towards Overseas Chinese entrepreneurs in Hawaii and South East Asia during the late nineteenth and early twentieth centuries or the double disenfranchisement that Filipina maids endure today while working abroad in hosting communities such as Singapore or Hong Kong - need to be put in perspective with the European philosophical roots of today's nation-state system in order to understand the inherent patterns of biopolitical governance.. He argues that policymakers use these ideas and epistemes for the purpose of legitimation, thus overwriting the disenfranchisement of migrant workers and other "incomplete" subjects together with other negative social effects that are triggered despite the rational telos of their policies. At the same time, however, these same states brand themselves and claim international recognition on a different register, namely by invoking the symbols, narratives and moral values pertaining to (invented) Asian traditions (Cheah 2006). Recently, Sinophone cultural texts have begun to reflect the moral and political consequences of an emergent "body turn" in the global neoliberal economy (Scheper-Hughes and Wacquant 2002), as is perhaps most visible in narratives dealing with the consequences of the 1990s' experiments with blood selling and China's one-child policy (Ma 2012; Mo 2009; Yan 2006).

In the following, I will analyze Mo Yan's fiction as an example of a critique of the serialization of human life and the treatment of human subjects as disposable bodies trapped within a framework of scientific modernization in the context of the Dengist economic reforms. The turn to a European enlightenment-based political 
economy and the embedded universal, scientific truth claims could not stem the deterioration of contemporary China's social realities, but instead produced new, post-revolutionary inhuman conditions, such as forced late abortions and a booming trade with human bodies - in this novel's case babies, young children and surrogate mothers. I will read the novel as an eerie response to Swift's Modest Proposal, ${ }^{3}$ wherein he had criticized as cynical the British state's turn to scientifically rationalized solutions in order to help its Irish subjects to escape poverty. According to his satire, to create surplus value from butchering the surplus population and letting it enter the commercial food circuit would be the ultimate scientific solution to an otherwise far too complex political problem. In Mo Yan's novel, the state apparatus continues to pursue scientific methods despite their ugly side effects. The social realities created by the science-based, serial birth control were only recently brought to the attention of a broader public sphere, however. In its humanist concerns, the novel does not appear to be too far from Swift's fictitious proposalwhich is why it hopefully will lead readers to contemplate some disturbing questions about global modernity's entanglements with a post-secular scientism that is arguably more harmful to the moral economy of a society than the muchmaligned local religious traditions declared superstition by state authorities.

\section{Encountering the aporia of globalization: the limits of science and aesthetic realism}

In early June 2012, The New York Times and other global news media reported in great detail on a Chinese lawsuit. Twenty-three-year-old Feng Jianmei from Yuping village in Zhenping county, Shaanxi province, claimed to have been forced into the abortion of her 7-month old foetus by officials representing the local birth-planning authorities. It was her second pregnancy, the first child being a girl. Married to a rural citizen, she would have been entitled to have a second child, but there were problems with the residence status (hukou) of the couple. Therefore, she was prompted to apply for an adaptation of her documents, to which later a fine was added. In the course of events this amounted to official payment claims of altogether 40,000 yuan-a sum entirely beyond the financial means of the couple, who therefore went into hiding, planning to give birth illegally. After the officials had chased her down and enforced abortion, her relatives took a picture of the hospitalized woman lying next to her dead baby and appointed a lawyer to defend Feng's rights. These images were also circulated in the digital media. Meanwhile, her husband secretly traveled to Beijing in order to seek justice. The story shocked both China's urban middle-class and Western news media audiences. ${ }^{4}$

\footnotetext{
3 'A Modest Proposal For Preventing The Children of Poor People in Ireland From Being Aburden to Their Parents or Country, and For Making Them Beneficial to The Public By Jonathan Swift' (1729), at http://art-bin.com/art/omodest.html (Accessed 19 Nov 2012).

4 See http://www.nytimes.com/2012/06/27/world/asia/chinese-family-in-forced-abortion-case-still-underpressure.html; http://china.caixin.com/2012-06-13/100400370.html; http://tech.92jn.com/weibo/redian/ 2012/0613/92890.html (Accessed 6 July 2012).
} 
Even though the facts of the case may not have been represented entirely truthfully, and the appetite of global audiences for this kind of "geopoliticized evil" may be as scandalous as the sad facts behind a generic millenium story, it raises pressing questions concerning the moral legitimacy of a political solution that apparently causes more problems than it can solve. The drastic measures taken to enforce birth control in rural China verify those serious doubts about the ethics of scientifically engineered demographic policies that were articulated earlier by Jonathan Swift. When he anonymously published his Modest Proposal in 1729, he provoked his readers with the suggestion to redress Irish poverty and overpopulation by means of an institutionalized, commercial infant cannibalism. His satire lampooned the British enlightenment infatuation with a scientific revolution that was perceived to have a shocking flipside. In particular, William Petty's (16231687) application of political arithmetics for land confiscation as well as this same author's ideas about social engineering as expressed in his Political Anatomy of Ireland were derided by Swift as cynical, destructive assaults on human dignity. ${ }^{5}$

The fictional works of 2012 Nobel laureate Mo Yan are worthy of appraisal for their thought-provoking perspectives on the cultural impact of European values on China's modernization-in the novel Wa (Frogs 2009), for instance, an astute variation on the inhuman scientism in Swift's Modest Proposal is offered. When confronted with Chinese realities, Western theories in many of his narratives unfailingly expose their weaknesses and culminate in irrational assumptions. Focusing on his taste for satirical exposures of Chinese modernizers' infatuation with Western science-based thought, Mo Yan has frequently been accused of being a nationalistic writer who rejects all that is of Western origin lock, stock and barrel. ${ }^{6}$ However, his inquiries into the outcome of the succession of modernizing policies through the nation's historical vicissitudes and their impact on its rural peripheries are more than mere refutations of concepts considered foreign, Western or unChinese. Rather, his writings suggest that the strategies of their implementation

\footnotetext{
${ }^{5}$ McCormick concludes his study on W. Petty: 'Looking backwards, it is easy to talk about Petty's economics or his demography and to dismiss or ignore his alchemy or even his politics: but this is not only to oversimplify, it is to miss the point. Petty's successors enunciated more carefully than he did the idea of a value-neutral science of society. However, they pursued their own brand of social engineering no less ruthlessly, and much more effectively. The forced movement, mixture, and separation of populations did not stop in 1687. On the contrary, it had scarcely begun. From the slavery and transplantation of Petty's day to the eugenics, ethnic cleansing, and nation-building more familiar to our own, the connection between analyzing populations and manipulating them has been often hidden but never cut. If Petty...tells us anything, it is that the history of social science, which is to say the history of our own pre-eminent world-view, has always been about both' (McCormick 2009, p. 305).

${ }^{6}$ Examples of this kind of verdict include Gries (2004, p. 42); Yue (2005). In a more sophisticated reading of Mo's novel 'Fengru feitun' (Big Breasts and Wide Hips), Cai Rong subscribes to the analytical paradigm of a nationalistic narrative: 'My focus in this chapter is on how the sexual transgression in 'Fengru feitun' turns into an issue of national sovereignty and subsequently develops into a violent and intricate confrontation between the Chinese self and the foreign Other. I argue that this preoccupation with sexual propriety is informed with some latent anxieties toward the Chinese self. In particular, I discuss how the nationalist urge to disempower the foreign Other evolves when male sexuality is equated with self-identity, national dignity, and paternal authority to become the center of contention' (Cai 2004, p. 155, passim). I have argued elsewhere that nationalism in the guise of the sexually anxious male self is not necessarily at the center of contention, and that it is not the most challenging aspect of this novel (Riemenschnitter 2011, pp. 418-432).
} 
resulted in fatal entanglements of local realities with transnationally circulating norms, ideas and theories. In other words, it is the pseudo-religious veneration by the ruling elites for the magical powers of an alien knowledge system that bears responsibility for things going awry in and beyond Mo Yan's semi-fictional Gaomi county. Besides revisiting the most powerful modern myths of revolution, progress and enlightenment and investigating their impact on this particular local community, Mo's novels also tackle the local educated elites' difficulties to fulfill their new roles, which implied a shift from being the initiated transmitters of local, sedimented knowledge to becoming culturally uprooted mediators of alien epistemes. As a consequence, his aesthetic project pursues a double trajectory: to expose the grim realities the political economy of modernization has created in the Shandong countryside and to understand the interference of modern, universalist concepts with the time-honoured, sedimented experiential knowledge in a local environment (Riemenschnitter 2011, 2012). Contrary to the earlier realist writers, Mo's novelistic approach denies the critical intellectual an independent stand aloof of the social realities he (or she) observes. It also turns away from the modernist belief in a universal humanism based on progress and science-based government. Rather, it proposes a move towards the disentanglement from a set of values that can no longer stand up to the promise of benefit for the local multitudes-and thus for the whole planet.

Wa's return to the realist mode at first sight seems anachronistic. Since the demise of the Qing Empire, Chinese authors have continuously revised their aesthetic programs, and during the 1940s literary realism became the leading modernist mode. ${ }^{7}$ Exposing the grimly fixed social inequalities of China's feudalist culture(s), it set out to bridge the gap between the writers' critical intellect and a declining social order, and thus to create the desired new national self. However, even during its most widely acknowledged periods of practice, this mode could not fulfill the modernizers' expectations. This is why authors writing after the end of the Cultural Revolution (1966-1976) started to put into question the stereotypical victims of the old world order as much as the new realist heroes. After the CCP control over the aesthetic paradigms of socialist realism was loosened, this new generation of writers began to explore alternatives to this mode (Anderson 1990; Button 2009). They drew inspiration from the hitherto neglected local traditions and once again turned toward the long-vilified classical heritage of national poetics. Moreover, Latin American magical realism as well as poststructuralist techniques like pastiche, bricolage or metafiction added color to the new expressive styles developed since the 1980s. The new narrative strategies were implemented in order to unearth and revisit those forgotten or suppressed memories, unresolved contradictions, residual values and beliefs that were circulated in the legends, rumors and post-secular

\footnotetext{
7 The intellectual departure that strove for the implementation of a new culture based on vernacular language and a radically modern/Westernized worldview is known as the May Fourth movement. Named after the student demonstrations on 4 May 1919 against the Japanese acquisition of the former German colonies in the wake of the Versailles negotiations, the epoch roughly covers the years between 1915 and 1927. For a recent reassessment of the role of May Fourth intellectuals and their ideas in China's cultural modernization see Chow et al. (2008).
} 
rituals that continued to hold together regional communities at the margins of the modern national pedagogy.

Observing how the state adopted a discourse on scientific modernization, thereby reconstructing the $\mathrm{CCP}$ regime by means of their scientifically legitimated enforcement policies, Mo and a number of other authors with a 'zhiqing' (rusticated youth) background reconsidered their aesthetic program during the early 1990s. They developed experimental modes of writing that reached far beyond the strictly local. With Maoism and its anti-intellectual thrust obsolete and first hints at the systemic inhumanness of Deng's scientific regime already leaking through the new slogans, the grassroots perspective that had been adopted in a movement called 'xungen' (searching for the roots) during the 1980s now steered a pluralization of literary pursuits. This led to interesting writing trends, such as a corpus of recently acclaimed new historicist novels ('xin lishi xiaoshuo') or lower class writing ('diceng xiezuo'). Authors continued to comb classical as well as contemporary language registers in their recalibrated search for vocabularies of distinction vis-àvis both the Chinese state discourse and the Western hegemonic model of a global modernity (Lai 2009). Mo Yan shares with these writers a focus on the nation's disenfranchised subjects. In particular, he is concerned with the old and new forms of subalternization that the rural population is submitted to under the postrevolutionary regime.

If we follow Wang Hui and other critical observers of China's quest for a legitimate, unique position in the emergent world order, today's avant-garde intellectuals no longer seem to envision superficial readjustments of the program of modernization to Chinese realities, but rather seek to deconstruct the paradigms and epistemes of this global modernity itself. A critique of the problem of China's modernity in the era of global capitalism, argues Wang, must transcend the ideological constraints of enlightenment thought and tackle the uniquely Chinese, post-Cold War convergence of the two opposing ideologies of capitalism and socialism (Wang 2001). In particular, their common underlying values and shared assumptions derived from scientific methodologies such as statistics and quantitative studies of social phenomena must be critically evaluated. Writing Wa, Mo Yan seemingly responded to this call for a critical revision of the paradigms of scientific modernism. He seemingly returned to the battered realist mode after a long period of successful experiments with postrealistic narrative techniques. A possible way to understand his choice is to see at work a principle of confronting the observed realities with the aesthetic program that has enforced their production.

\section{Social engineering and furious modelling: $W a$}

The paradigms of science and technology were part of the Chinese educational and mass cultural policies even before the regime announced that a pending demographic crisis required revisions of the prevailing laws. In 1971, Zhou Enlai had issued the formula: 'one child is ideal; two are enough; three are too many'. After Mao's death, however, rigorous social engineering replaced Zhou's attempts to reach a consensual practice by means of the local interaction between family 
planning agents and the population. In 1978, birth planning was incorporated as a law in the constitution, and in 1980 reforms to the one-child-policy were discussed and ratified in the National People's Congress. It was not unsuccessfully disseminated in the urban centers, while the majority of the population in the countryside continued to go around it until violators were submitted to legal persecution, high penalty fees, forced abortions, and other enforcing measures. ${ }^{8}$

The paradigm shift from birth-control encouragement to enforcement came with the appointment of a hardcore scientist. Shandong Rongcheng county scion Song Jian, who was one of Maoist China's foremost defense scientists and as such had been on Zhou Enlai's protection list throughout the Cultural Revolution, was sent to Helsinki in 1978 to attend the Seventh Triennial World Congress of the International Federation of Automatic Control. There he got acquainted with the newest variant of a cybernetic population control method authored by two Dutch control theorists from the network of the Club of Rome. Song seized the opportunity to apply systems science and a quantitative approach to a field so far controlled by social scientists. In the years to follow, he developed his own demographic model while continuing to work in missile and aerospace science (Greenhalgh 2008, pp. 128-132).

Many of the hitherto responsible social scientists, who were working according to the doctrines of Marxist humanism and had a background of qualitative training including fieldwork experience, disagreed. Liang Zhongtang and Zha Ruichuan, for example, strongly opposed Song's new science-based approach on the grounds that, 'given the realities of peasant family culture and economy, the likely social consequences of a one-child-for-all policy were so worrying as to require a different policy altogether'. They were, however, quickly marginalized and silenced (Greenhalgh 2008, 256f). More than 20 years of 'one-childization' had to pass until independent scholars, artists and journalists ministered to draw wider public attention to the glaring social problems created by the strict implementation of Song's quantitative policy in rural areas. ${ }^{9}$

Mo Yan's novel $W a$ addresses these issues by means of a local history written in four chapters that are framed as letters sent to an eminent Japanese writer whom the letterwriter admires. This Mr. Sugitani, a proxy of Mo Yan's esteemed colleague Kenzaburo Ōe, ${ }^{10}$ visits the protagonist's hometown shortly before the letters are written and expresses his fascination with the story of a retired obstetrician, who is the I-narrator's

\footnotetext{
${ }^{8}$ Neurath $(1994,156$ f.) reports the case of a Stanford University doctoral student of anthropology who was expelled upon the publication in a Taiwan magazine of an article on his research in a Chinese village in 1983. His critique of forced third-trimester abortions was illustrated with pictures of the procedure with the faces of the women unmasked. Representatives of the Chinese government protested against the publication of these materials, claiming that they were fake or deliberately exaggerating. A few months later a British TV team was allowed to produce a documentary which asserts what had been stated in the student's article.

9 Ye Tingfang, '30 years of Birth Planning - The Price Paid by the Nation and the People is High.' In: Zhongguo xiangcun faxian, 5 May 2010. Available at http://www.zgxcfx.com/Article_Show.asp? ArticleID=23611. (Accessed 14 July 2012). See also further reading materials indicated there.

${ }^{10}$ In the preface to the Taiwanese edition, the author mentions a visit of Kenzaburo Ōe and their exchange on his plans to write a about his aunt, see Mo Yan, "Ting qu Washeng yi pian" (Mo Yan, Wa, Taipei: Maitian 2009, p. 003). I thank the German translator of the novel, Martina Hasse, for alerting me to this edition and the Ōe reference.
} 
aunt. A final stage play supplements the patchwork text. In the letters, the I-narrator tells the story of his aunt Wan Xin, who belongs to the first-generation of China's modern medical professionals. From her childhood days during the Sino-Japanese war, when she and her mother were taken hostage by a Japanese general, to her retirement around 2000, the region's exposure to extreme historical vicissitudes reverberate in her ambivalent role as both midwife and birth control officer, which compelled her to oscillate between being a savior and an annihilator of life.

On the level of the sociopolitical body, $\mathrm{Wa}$ allegorically links the last phase of aunt Wan Xin's professional career, accompanied by a wide range of illegal abortions and violations of the one-child policy under conditions of the latest consumer capitalist excesses, to the community's earlier traumatic experiences. Not surprisingly, an oral history of the Maoist famine years constitutes a kind of will-o'-the-wisp motif in the novel, as their memory uncontrollably resurfaces and repeatedly misleads the protagonists in their consumption desires. Furthermore, the educated elite reveal an alarming numbness with respect to the dignity of human life itself: in $\mathrm{Wa}$ the bodies of peasant babies become either superfluous, dead waste material, or precious, carefully bred live-stock. The transition is reflected on many levels; a telling example are changes in the practice of naming the new-born children. Whereas a notion of incomplete subjectivation was traditionally articulated by the rural community through the practice of assigning their children human body part names, the new age children more likely bear the imaginary, delocalized and disembodied names of TV series protagonists from Hong Kong, Taiwan or Japan:

Sensei, we observe an ancient rule in the place where I live. New-born children are named after body parts or bodily organs. For example Nose Chen, Eye Zhao, Colon Wu, Shoulder Sun...I did not investigate the ideational roots of this custom; it most likely has something to do with a mentality reflected in the saying 'those with a humble name live long'. Or else it is because of mothers' inclination to treat their children as a piece of their own flesh. Today this custom is no longer fashionable. Young parents are no longer willing to give their children such weird and antiquated names. Nowadays the children from my place bear sophisticated, unconventional names like those of the protagonists of TV series made in Hong Kong, Taiwan, and even Japan and Korea. Even the majority of those children who still bear names after body parts and organs have changed them into more elegant ones, but of course there are also those who have kept them, like Nose Chen or Eyebrow Chen. (Wa 2009: 5; my translation.)

This shifting naming practice on the one hand hints at earlier local variants of biopolitical regimes, and on the other hand exposes the dynamics of an inundation - which is in fact a conjunction - of the traditional, locally rooted mindset with the contemporary, ephemeral cultural imaginary of TV watchers and netizens. A similar process can be observed with respect to the changes that happen in-between Wan Xin's experiences in assisting at her first birth and her last time on duty. The first baby sees the light of day after she has boldly chasen away a traditional midwife who tried to apply some shamanistic magic to the mother in labour. Roughly 50 years later, her nephew's second child requires her assistance some time after she 
has officially retired. This child was carried to term clandestinely, upon in vitro fertilization, in a bullfrog farm; thus, her service needs to be delivered in a circuitous, hidden way. ${ }^{11}$

At the beginning of her career I-narrator "Tad-pole" Wan Zu's aunt, who is the daughter of Norman Bethune's disciple, is fully confident in both herself and the new political system. She is proud of her superior method that is based on advanced medical knowledge, technological equipment, and a political orientation that however later turns out to yield much more serious consequences than the disposed traditional midwives' useless charms. After her having administered several thousand childbirths with great success, politics change dramatically: the government turns from encouragement to a tempered restriction of women's fertility. A period of education and soft control through campaigns for contraception is quickly followed by compulsory implantations of IUDs and vasectomy immediately after a couple's first child is born. Under the reformist regime of Deng Xiaoping and his successors, science-based seriality becomes the key principle: from then on, nobody is allowed to transgress the rule of party law. On the grounds that the previous, soft measures did not yield the expected success rates in the countryside, the young obstetrician turns into one of the main perpetrators in the merciless persecution of pregnant women, carrying out hundreds of forced abortions. Under her surveillance nearly one thousand babies and several of the mothers die.

By the time the obstetrician retires in 1997, she has assisted in the birth of thousands of children, but there is no reason for her to take pride. She is disturbed by the memory of those hundreds of infants she intentionally killed in dutiful—and sometimes overzealous - fulfillment of her official mission. Her feelings of guilt take command over her life after an incident during the last rite of passage. A village banquet with a rich supply of hard liquor, organized on occasion of her retirement, ends with her delirious descent into a surreal, psychedelic landscape. Attacked by a pack of frogs and sucked into the marsh-like ground, ${ }^{12}$ she runs for her life, experiencing fits of extreme horror and pain. A peasant artisan finds her in this state of nervous breakdown, takes her to his home, nurses and later marries her. In constant fear of revengeful ghosts, she obsessively enacts her private serial recreation project by modelling her husband's handicraft production of temple market clay babies (ni wawa) after the facial features of the deceased. Though permanently disoriented, she also performs her professional role for one last time, bringing to life the narrator's second child, the above-mentioned son who was clandestinely 'harvested' from a surrogate mother. This woman belongs to a group of 'employees' managed by the bullfrog farm entrepreneur whose, illegal business is to hire and rent out these female procreative bodies.

\footnotetext{
${ }^{11}$ The outlook on life and the role of the human body in contemporary subject constitution links this scientifically engineered, industrial child production to global trends in view of the relationship between biopolitics, power and medicine. See, for instance, Rose (2007).

12 The Chinese character for frog, wa 蛙, is homophone with the character wa 娃, baby. It also extends to the second part of the character for the mother goddess Nüwa 女娲, who according to the myth created humankind by using mud to form clay figurines whom she then bestowed with the breath of life. The enactment of a reverse creation myth as revindication by the frog-shaped ghosts of the murdered babies explains the title of the novel. For the episode see Wa (2009, pp. 210-217).
} 
The novel raises many questions, for instance: how do the obstretician and her helping hands, who are mostly highly educated elite subjects, cope with the moral consequences of their hideous mission, and how does this inhuman practice impact on the collective, sociopolitical body? On the level of subjects, the narrative investigates a range of human responses from the point of view of both victims and perpetrators, taking into account that the boundaries between these two categories may be blurred. On the one hand, Aunt Xin sees herself as a patriotic heroine and woman of the highest moral standards; from her early childhood experience as a Japanese hostage to the time when she retires she knows no fear and shows exceptional courage and pride. When it is made public that her fiancé, a Guomindang air force pilot, is a traitor who escaped to Taiwan, she feels so humiliated that she attempts to commit suicide. Later, during the Cultural Revolution and afterwards, she remains faithful to her principles even under physical torture. Likewise, she is so uncompromisingly committed to the Party directives that even her own nephew's wife cannot escape her: young Wang Renmei dies under her hands from the consequences of late abortion. Wan Xin systematically tracks down every single villager who attempts to transgress the birth rate and does not give in until the unborn child is eliminated. Only in one case she fails because the mother gives premature birth. Upon her death from exhaustion, this baby girl is saved and temporarily raised by the nephew $\mathrm{Wan} \mathrm{Zu}$ and his second wife. Only much later the obstetrician is shown to be deeply disturbed by the deaths she has inflicted. That her predicament must be seen as a sinister twist of the Abrahamic aporia-since no God appears to save her from killing her nation's unborn sons and daughters-is clarified in her rigid moral stance towards abortions outside the one-child policy: she indignantly rejects all selfish requests for such medical interventions brought forward by the newly rich, powerful capitalist patrons of young girls. The power of money works itself through different agents.

This is not to say that the two forces of money and moral conscience never collude, though. As mentioned above, a grotesque sequel to Dengist birth control policies unfolds under the Hu-Wen regime, when the narrator, already in his 50s, expects his second child. The surrogate mother of this baby boy, now in her early 30s, has already miraculously overcome two deadly perils: first she narrowly survived abortion as an 8 months-old foetus and then, as a young migrant worker, her life was spared upon a blaze in a toy factory-which however left her defaced and disfigured. The novel's grotesque realism culminates in this figure of the 'onechildized' rural population and their struggles for a better future, as they find themselves more and more thrown back into a social pattern of the past: the ruthless exploitation by a privileged class that, not so long ago, they believed was forever overcome. In comparison, rumors about the involvement of functionaries in the trafficking of peasant children and subsequent sales to prospective adoptive parents hint at a social reality that arguably threatens to outperform the fictional scenarios in this novel. ${ }^{13}$

\footnotetext{
${ }^{13}$ See BBC, 10 May 2011, available at http://www.bbc.co.uk/news/world-asia-pacific-13350757 (Accessed 14 July 2012). More recently, news about cross-border male infant trafficking from Vietnam are spreading.
} 


\section{Conclusion}

Seen in the light of Swift's Modest Proposal and its contemporary echoes, ${ }^{14} \mathrm{Wa}$ tells a similar story from historical hindsight. Upon the hapless implementation of misunderstood enlightenment arithmetics, the Chinese text can only suggest another disengagement. This time around, the second, initially successful modernizing experiment, neoliberal reformism, is shown dangerously to incline towards Mao Zedong's failed revolutionary path when it comes to human dignity. In various respects, Aunt Xin continues to misrecognize the nation's (subaltern) subjects as intimate enemies (Cheah 2013; Nandy 1983, Thompson and Yar 2011). The author's reference to Sartre as a literary model for the fictitious playwright Tadpole, as expressed in the first letter to Sugitani, can thus be read as an attempt to translate the French philosopher's reflections on seriality in his Critique of Dialectical Reason into a Chinese response to Dirty Hands and The Flies. ${ }^{15}$ Defining a lack of group consciousness among the powerless multitude as the precondition for its political impotence, or defenselessness vis-à-vis the privileged and organized elite groups as one part, and the systemic lack of reciprocity in public communication patterns as the other constitutive part of global humanity's serial existence, Sartre had analyzed the historical failure of both capitalist and (Sovjet) communist political systems to restore social harmony and create a sustainable relationship among the various-human as well as non-human-inhabitants of the planet (Catalano 2010, pp. 43-68).

A spectralized Gaomi modernity that is still haunted by the ghosts of wars and revolutions now exposes the superficial implementation of scientific governance in the Chinese hinterlands, where the population remains under-educated and with little access to the beneficial aspects of the nation's economic miracle. Whereas Aunt Xin's surveillance is conducted in a most efficient way, the incentives and disincentives for birth control ${ }^{16}$ reach the peasants only in the shape of unmediated bare life enforcement. Following Pheng Cheah's analysis of purpose-oriented 'huaqiao' (Overseas Chinese) and migrant Filipina identity ascriptions by global capital in Southeast Asian neo-colonial states, ${ }^{17}$ we can observe that the biopolitical

\footnotetext{
14 See the various youtube versions circulating on the web as well as the scorching satire of Western totalitarianism by Régis Debray (C and Debray 2004).

15 Wagner and MacLean add an interesting aspect to Sartre's notion of seriality, observing its dynamics in the intersection between television programming, consumerism and buying, and crime, arguing that repetitiveness and banality constitute the affective matrix of both consumerist desires and serial crime: "In televison's traditional endlessness and its meaningless choices lies banality. Certainly, any discussion of seriality refers to the idea of television as banal, repetitious, and undifferentiated. This is also the banality of the horrific - the serial killer is also banal, repetitious, and undifferentiated." See Wagner and MacLean (2008, p. 48).

16 The regulations are reproduced in detail in Neurath (1994, pp. 161-166).

17 See Cheah (2006, pp. 120-143, passim). See also his analysis of the spectral character of finance capital: 'Finance capital is profoundly spectral in nature: national modernization and revolution, after all, need to be financed... The governments of hyperdeveloping East and Southeast Asia are not merely comprador states in the strict Marxist sense of the word. They are often vocal in their policy disagreements with and ideological opposition to Northern or Western governments...The thematic distinction and occasional doctrinal skirmish between crony capitalism and visions of world trade liberalization (transnational capitalism) remain part of the configuration of postcolonial capital, a structure that ultimately rests on and is sustained by the exploitation of the masses of Asian Pacific
} 
spectralization extends to the modern professional subject, who is trained to bring the life-prolonging fruits of advanced medical knowledge to the masses, but is then ordered to toe to the party line and abuse her expertise to work against the peoples' interests, thus enacting a thanatopolitical tragedy.

The mock realism of $W a$ stages the interaction between official agents of governance, local stakeholders and the people as an autopoetic, grotesque, and inhuman practice that destroys both human relations and the environment. With the return of a transmogrified version of the ancient creation myth of Nüwa ${ }^{18}$ in the role of serial abortionists who are in fact victimized victimizers, modernist secularization is exposed as a cynical capitalist bricolage leading humankind back into the mindset of archaic mythologies. Behind the façades of a glamorous urban culture lurks a redundant, haunting, atemporal space, whose bemused inhabitants appear both misguided and isolated in their struggles for a better life. The I-narrator Kedou (Tadpole)_himself being both victim and co-perpetrator regarding his aunt's abortions and his second wife's hiring of a surrogate mother-is a modern intellectual who inwardly disagrees, yet passively goes along with these unethical transactions. His complicity with the scientific state, or rather with the serial logic of its representatives, turns him into a particularly uneasy narrator.

Finally, the frogs in the novel's title require critical attention as symbols of an atavistic force. By way of homonymy they are linked with both human infants and the goddess Nüwa. Moreover, as is explained in the narrative, they represent fertility based on their overabundant reproduction output. They appear wherever something is absently present in the narrative. The allegory starts with the nom-de-plume of a guilt-plagued I-narrator (Tad-pole), extends to the frog-shaped ghosts of the aborted children who haunt aunt Xin after her retirement, and is reinforced with the image of a fake bullfrog farm where illegal childbirth business is run. Accompanying the retired aunt's furious modelling of one clay baby (ni wawa) for each child that was aborted during her career, the frogs represent a category of not-yet-humans. In other words, the frog marks a figure of the abject in the Gaomi community. This abject, as a radically excluded, constitutive 'primal repression' of a pre-symbolic neithersubject-nor-object that disturbs identity, system, and order and respects no borders, positions, or rules (Kristeva 1982, p. 4), does not only reside in the materiality of the dead bodies and their symbolic return as frogs, but also in the position of occidental modernity in its relationship to the modernizing Chinese nation. Before traveling through the various phases of a Chinese modernity, the occidental slogans of science and democracy were first popularized by Chen Duxiu to support the May Fourth luminaries in their project to modernize the nation. Although temporarily successful in their attempts to foreclose, with various strategies of empowerment and marginalization, alternative conceptions of development, these intellectuals were not without doubts with respect to the imported, alien values. This allows us to

\footnotetext{
Footnote 17 continued

nations in the name of free trade and development...The high economic performance of these East and Southeast Asian nation-states is induced largely by the spectrality of finance capital' (Cheah 2006, 141f.).

18 Nüwa is an archaic goddess of creation. For her role in modern and contemporary narratives see Riemenschnitter (2011, 80 f., 389 f., 411 f., passim).
} 
reread their literary realism in the discursive framework of the Dengist regime. $W a$, in this line of argument, allies with the regionalist explorations of non-elite life and sustainable survival knowledge, but transpositions the May Fourth abject: from the counter-modern acculturation of the modernizing self as ex-subject of a feudal state (and its contemporary shadow, the restrained 'literati' narrator), to the irrational instrumentalization of the modern as internalized other (the modern obstretician who murders in the name of the modernizing state). Mo Yan thus evokes the folklore, the popular moral values and the human instincts as a suppressed forms of local knowledge that challenge the modern universalist ratio. Hinting at the lack of non-violent political solutions for the rural population, his narrative implicitly takes the post-revolutionary bureaucracy to task for its alliances with the center, the city, and science, as well as for its complicity with global finance. In this sense, the neoliberal state's adopted occidental modernity inherits - and shatters - the position of a May Fourth abject, which once was the yet-to-be-eliminated, residual legacy of the feudal state. ${ }^{19}$

\section{References}

Anderson, M. (1990). The limits of realism: Chinese fiction in the revolutionary period. Berkeley, CA: University of California Press.

Braidotti, R. (2006). Transpositions: On nomadic ethics. Cambridge: Polity.

Button, P. (2009). Configurations of the real in Chinese literary and aesthetic modernity. Leiden, NL: Brill.

Cai, R. (2004). The subject in crisis in contemporary Chinese literature. Honolulu: University of Hawaii Press.

Catalano, J. S. (2010). Reading Sartre. Cambridge, UK: Cambridge University Press.

Cheah, P. (2006). Inhuman conditions. On cosmopolitanism and human rights. Cambridge, MA: Harvard University Press.

Cheah, P. (2013). The biopolitics of recognition: Making female subjects of globalization. Boundary 2, 40 (2), 81-112.

Chow, R. (2007). Sentimental fabulations, contemporary Chinese films. Attachment in the age of global visibility. New York, NY: Columbia University Press.

Chow, K.-W., Hon, T. K., Ip, H. Y., \& Price, D. C. (2008). Beyond the May Fourth paradigm: In search of Chinese modernity. Lanham, MD: Lexington Books.

Debray, R. (alias Xavier de C) (2004). Empire 2.0: A modest proposal for a United States of the West by Xavier De C. Berkeley, CA: North Atlantic Books.

Devinney, T. M., Auger, P., \& Eckhardt, G. M. (Eds.). (2010). The myth of the ethical consumer. Cambridge, NY: Cambridge University Press.

Greenhalgh, S. (2008). Just one child: Science and policy in Deng's China. Berkeley: University of California Press.

Gries, P. H. (2004). China's new nationalism: Pride, politics, and diplomacy. Berkeley, CA: University of California Press.

Haraway, D. J. (2008). When species meet. Posthumanities, vol. 3. Minneapolis: University of Minnesota Press.

Kristeva, J. (1982). Powers of horror: An essay on abjection. European perspectives. New York: Columbia University Press.

Lai, M. (2009). Nativism and modernity: Cultural contestations in China and Taiwan under global capitalism. Albany, NY: SUNY Press.

\footnotetext{
19 I would like to thank Yiu-fai Chow and Jeroen de Kloet for inviting me to take part in their thoughtprovoking workshop "Looking after Europe" at the University of Amsterdam in May 2011, as well as for their valuable comments and revisions of an earlier version of this paper.
} 
Ma, J. (2012). Yin zhi dao (The dark road). Taipei: Yunchen wenhua.

McCormick, T. (2009). William petty and the ambitions of political arithmetic. Oxford, NY: Oxford University Press.

Miller, L. (2006). Beauty up: Exploring contemporary Japanese body aesthetics. Berkeley, CA: University of California Press.

Mo, Y. (2009). Wa (Frogs). Shanghai: Shanghai wenyi chubanshe.

Nandy, A. (1983). The intimate enemy: Loss and recovery of self under colonialism. Delhi: Oxford University Press.

Neurath, P. (1994). From Malthus to the Club of Rome and back: Problems of limits to growth, population control, and migrations. Armonk, NY: M.E. Sharpe.

Riemenschnitter, A. (2011). Karneval der Götter: Mythologie, Moderne und Nation in Chinas 20. Jahrhundert. Welten Ostasiens. Bern: Peter Lang.

Riemenschnitter, A. (2012). Mo Yan. In T. Moran (Ed.), Chinese fiction writers, 1950-2000 (pp. 179194). Detroit: Gale.

Rose, N. (2007). The politics of life itself: Biomedicine, power, and subjectivity in the twenty-first century. Princeton, NJ: Princeton University Press.

Scheper-Hughes, N., \& Wacquant, L. (Eds.). (2002). Commodifying bodies. London: SAGE.

Shelley, L. (2010). Human trafficking: A global perspective. Cambridge: Cambridge University Press.

Thompson, S., \& Yar, M. (Eds.). (2011). The politics of misrecognition. Franham, UK: Ashgate Publishing Ltd.

Wagner, J. N., \& MacLean, T. B. (2008). Television at the movies: Cinematic and critical approaches to American broadcasting. Bodmin: Continuum International Publishing Group.

Wang, H. (2001). Contemporary Chinese thought and the question of modernity. In X. Zhang (Ed.), Whither China? Intellectual politics in contemporary China (pp. 161-198). Durham: Duke University Press.

Wilkinson, S. (2003). Bodies for sale: Ethics and exploitation in the human body trade. London, NY: Routledge.

Yan, L. (2006). Ding zhuang meng (The dream of Ding village). Shanghai: Shanghai wenyi.

Yue, T. (2005). China's new pride. The new Chineseness: Great leap forward or backward? IIAS Newsletter, 37, 7 .

Andrea Riemenschnitter is Chair of Modern Chinese Language and Literature at the University of Zurich, Switzerland. She received her Ph.D. from the University of Goettingen in 1997 and completed her postdoc research at the University of Heidelberg in 2002. Her research interests include Chinese modernities, questions of social change and transcultural flows, as well as issues related to representation, performance, ethics, memory, imagination, identity and intertextuality. Her book-length publications include Karneval der Götter. Mythologie, Moderne und Nation in Chinas 20. Jahrhundert (Carnival of the Gods. Mythology, Modernity and the Nation in China's Twentieth Century, 2011), China zwischen Himmel und Erde: Literarische Kosmographie und nationale Krise im 17. Jahrhundert (China between Heaven and Earth: Literary Cosmography and National Crisis during the seventeenth Century, 1998), Diasporic Histories. Archives of Chinese Transnationalism (ed. with D. Madsen, HKU Press, 2009), Xian yu Yin/The Visible and the Invisible/Sichtbares und Verborgenes: Poems by Leung Ping-kwan (ed. and tr., Hong Kong: mccm creations, 2012), Ruishi A'erpisishan de chuanshuo/Legends from the Swiss Alps (ed. with Leung Ping-kwan, Hong Kong: mccm creations, 2009), as well as a German translation of Jia Pingwa's Taibaishan ji (Legends from Mount Tai, Berlin: LIT 2009) and a co-authored translation of Gao Xingjian's dramatological writings (2000). 